\title{
ЗА КРОК ДО КАТАСТРОФИ. ОРГАНІЗАЦІЯ ОБОРОНИ ПОДІЛЛЯ ПІД ЧАС СХІДНОЇ (КРИМСЬКОЇ) ВІЙНИ 1853-1856 рр.
}

У статті розглянуто превентивні оборонні заходи російського військового командування щодо вірогідного наступу військ Австрійської імперії на територію Подільської та Бессарабської губерній в період 1854-1856 pp. Доведено, що відсутність в російського самодержавства заздалегідь складених тактичних планів прикриття кордонів військами, дипломатичні прорахунки i нехтування зовнішньополітичною ситуацією у Східній Свропі та на Балканах, ледь на поставили Російську імперію на межу стратегічної військової поразки іiї збройних сил на теренах Правобережної України.

Ключові слова: Російська імперія, Поділля, Бессарабія, Східна війна, армія, оборона.

Постановка наукової проблеми та ї̈ значення. Перебіг далеких подій Східної (Кримської війни) 1853-1856 рр. й досі перебуває у полі зору дослідників країн Європи. Протягом більш ніж ста років написано чимало грунтовних та об’єктивних наукових розвідок, які неупереджено висвітлюють різні етапи збройного протистояння західних держав з Російською імперією, а майже усі автори сходяться на думці щодо агресивної сутності політики російського самодержавства в середині XIX ст. як іï причині. Разом з тим існує чимало поверхневих і заангажованих праць російсько-радянських істориків, де головною метою $\epsilon$ спотворення реального перебігу подій, виправдання імперських амбіцій Миколи I та нівелювання участі представників інших етносів, крім російського.

Однією 3 маловідомих подій тієї масштабної війни $€$ протистояння двох європейських імперій - Росії та Австрії. Розпочавшись у вигляді багатоетапних дипломатичних маневрів на передодні, воно переросло у справжню „холодну війну” 3 інтенсивними військовими приготуваннями та планами операцій,

Скрипник Анатолій Юрійович - доктор історичних наук, доцент, завідуючий кафедрою інформаційної діяльності, документознавства i фундаментальних дисциплін Подільського спеціального навчально-реабілітаційного соціальноекономічного коледжу, м. Кам'янець-Подільський.

(C) Скрипник А. Ю., 2018 
а у завершальній стадії ледь не призвело до відкритого збройного конфлікту на кордоні. Вивчення та висвітлення основних стадій імперського антагонізму та його наслідків й стало метою даного дослідження.

Аналіз останніх публікащій із цієї проблеми. Історіографія обраної теми міститься у великому масиві робіт, присвячених широковідомим подіям 1853-1856 pp., і має дещо дотичний характер. Генерали М. Ушаков [37], В. Аратовський [4], О. Петров [20], П. Алабін [3] у своїх працях, що побачили світ наприкінці XIX ст., кваліфікують їх як несподіваний агресивний крок 3 боку Австрійської імперії. Серед радянсько-російських фахівців варто виокремити Л. Бескровного [5], І. Ульянова [36] та А. Криволапова [11] 3 їх оцінкою загального стану царських військ на Поділлі і Бессарабії та планів вищого командування, які водночас уникають очевидних висновків. Тенденція студій сучасних українських дослідників полягає у висвітленні ще існуючих „білих плям” тієї війни. Тому варто звернутися до робіт О. Реєнта [29], А. Скрипника [31; 32], Р. Пилявця [21], які на основі джерельних матеріалів відображають досі не відомі події, факти та судження у сучасній, не заангажованій інтерпретації.

Метою наукової розвідки стало збирання, систематизація та поширення інформації про маловідомі події Східної (Кримської) війни та введення до українського історичного простору нового напряму студіювання.

Виклад основного матеріалу й обтрунтування отриманих результатів дослідження. Союз Російської імперії з Австрією довгі роки був традиційним для російської дипломатії ще 3 початку XVIII, а в обох імперій існував спільний ворог на Дунаї Оттоманська Порта. Водночас, вони були постійними конкурентами на Балканському півострові: одна не могла ступити кроку без того, щоб не випередити іншу. Обидві країни старалися крокувати разом не стільки допомагаючи одна одній, скільки слідкуючи за суперницею. Посилення Росії було послабленням Австрії i, навпаки: „союзниці” більш за все боялися, щоб одна не використала іншу у своїх односторонніх вигодах [23, с. 6]. Проте в середині ХІХ ст. ситуація кардинально змінилася.

Імперська зухвалість та войовничі настрої не дозволили Миколі I, його дипломатам, міністрам і генералам об'єктивно та тверезо оцінити зовнішньополітичну ситуацію в Європі та 
економічну спроможність Російської імперії. Ситуацію в Росії напередодні війни 1853-1855 pр. об'єктивно висвітлив ії учасник. „Ми не мали талановитих полководців, ні залізничних шляхів, ні гвинтових пароплавів та достатньої кількості великих кораблів; ні вдосконаленої вогнепальної зброї, яку мали всі європейські армії. Ми викликали на бій ворога, але не були готові до усіх несподіванок війни; не квапилися розпочати військові дії, а потім майже рік продовжували їх дуже повільно і нерішуче, так що важливі події застали нас зненацька. Уроки, отримані нами в цій тяжкій боротьбі, мають стати повчальними для нащадків," писав у своїх спогадах генерал-лейтенант М. Ушаков [37, с. 3].

14 червня 1853 р. обнародувано Маніфест про рух російських військ до придунайських князівств, ,[..] до тієї пори, поки не вдовольняться справедливі вимоги Росіі”, по суті - попередження про оголошення широкомасштабної війни Туреччині [1, с. 289290]. Незважаючи на те, що війська не були повністю готові, близько 80000 вояків вкотре утвореної Дунайської армії перетнули державний кордон і попрямували до Бухареста. Вона складалася 3 полків 4 і 5-го піхотних корпусів, які доукомплектувалися місцевими безтерміново-відпускними нижніми чинами при 196 гарматах під командуванням князя Горчакова [11, с. 247]. Факт агресії став наслідком i певною мірою закономірним результатом низки самовпевнених і невдалих кроків. Російська дипломатія ще до початку бойових дій зазнала поразки, оскільки не змогла заздалегідь визначити у війні із султанською імперією своїх ворогів та союзників, оцінити ставлення європейської громадськості до Російської імперії, об'єктивно визначити техніко-економічну відсталість, стан боєздатності армії та флоту за нових умов [29, с. 273].

Війська перетинали кордон двома колонами: до складу першої увійшли 4 і 5-та кавалерійські дивізії, донські полки № 34 і 37; 1-ша бригада 10-ї піхотної дивізії й 2-га бригада 15-ї піхотної дивізії перейшли річку біля м. Леова, друга колона, що складалася 3 решти військових частин - через м. Скуляни. Незабаром повільно потягнулися величезні провіантські обози, артилерійські парки та госпітальні підрозділи [26, л. 1 - 2, 9-10].

Наприкінці листопада 1853 р. Дунайська армія посилилася 3-м піхотним корпусом і загальна кількість військ склала 150000 солдатів. Однак майже одразу ж почала існувати реальна загроза 
оточення цих сил австрійськими військами. Фельдмаршал I. Паскевич, передбачаючи потенційні дії Відня, писав у своєму листі до Севастополя князю О. Меншикову: „[...] коли буде проти нас уся Свропа, то не на Дунаї ії потрібно очікувати [...] Австрія, маючи 230000 військ в Угорщині, Трансільванії й на сербському кордоні, пошле їх на Фокшани, Ясси і Кам'янець, у кількості 60-70 тисяч, нам у тил. Тоді наше становище буде таким тяжким, яким не було у 1812 році, якщо ми терміново не запровадимо належні заходи і укріпимо позиції по Дністру" [8, c. 257-258].

Однією 3 грубих дипломатичних помилок росіян стала недооцінка позиції Австрії. Місія дипломата О. Орлова у Відні, де він мав домогтися згоди Австрії на дружній нейтралітет у майбутній війні, зазнала фіаско. Одразу ж після його від’їзду австрійці розпочали мобілізацію армії й висування військ до кордону. Правда, насамперед на початку весни підкріплення спрямовувалися на кордон із Сербією, повстання в якій австрійці боялися не менше, ніж турки [11, с. 252]. Незабаром преса 3 тривогою писала: „Стверджують, що обидва австрійські прикордонні корпуси в кількості 50000 вояків займуть лінію між Крондштадтом і Тімешваром. Уряд планує сформувати ще корпус в 30000. В арсеналах пожвавлення, а 50 батарей (400 гармат) приведені в бойову готовність”[9, с. 3].

3'ясувалося, що до цих приготувань російське командування не було готове і не мало що протиставити можливому вторгненню австрійців на Поділля. Відповіддю на такі дії з боку колишнього союзника стало оголошення Подільської й Волинської губерній, які могли стати не тільки прифронтовими територіями, але й театром бойових дій, на військовому стані $з$ підпорядкуванням командуванню Діючої і Дунайської армій [2, с. 192-193].

Втім, усі резервні частини на той час були зосереджені далеко на півдні у Волощині. Лише в Бессарабіі, біля Херсону й Одеси стояла частина військ 5-го піхотного корпусу на військовому положенні (в бойовій готовності - А. С.), де завершувалося доукомплектування батальйонів із запасних солдат. Крім того, 3 цього корпусу 13 піхотна дивізія перебувала на роботах в Севастополі й отримала наказ бути готовою до посадки на кораблі Чорноморського флоту, а 4 і 5-й легким кавалерійським дивізіям тільки потім було призначено з'єднатися зі своїми корпусами в Бессарабії [30, л. 1-7, 47-50]. 
Однак серед більшості російського генералітету і населення панували оптимістичні настрої: вкотре поставимо на своє місце турок, а будуть чинити спротив - шапками закидаємо! Сам фельдмаршал I. Паскевич, князь Варшавський, недооцінював бойові можливості турецьких військ. Ще у вересні 1853 р. він був переконаний, що ,турецька армія [...] перебуває у пелюшках”. Чисельність регулярних військ султана, за його підрахунками, не перевищувала 60000 вояків. Запорукою успіху мала стати тактика, спрямована на виманювання турок з фортець, оточення ïx на рівнині та остаточному розгромі [7, л. 69 об.-70]. Усі забули уроки і досвід невдалої війни 1828-1829 рр., коли у випадку початкових сприятливих умов такий похід вимагав використання на Дунайському театрі значної кількості військ і ресурсів, що істотно послаблювало позиції на західних кордонах Росії.

Як наслідок, для прикриття та охорони західних кордонів Подільської губернії командування спромоглося направити незначні сили. Наприкінці квітня 1854 р. 6-та піхотна дивізія із 1-ю драгунською дивізією, уланською бригадою 6- ї легкої кавалерійської дивізії та 16-ю піхотною дивізією, всього близько 25000 вояків, розташувалися на австрійському кордоні в районі річок Серет $\mathrm{i}$ Прут та західних повітів Подільської губернії під командою генерал-лейтенанта графа Остен-Сакена, створивши таким чином заслін проти активних дій вірогідного противника. Проте цих сил було замало на випадок повномасштабного вторгнення австрійської армії, бойові порядки росіян були б легко прорвані, а великі території опинилися б під контролем Австрії [22, л. 13 - 17].

Поступова концентрація австрійських сил в Галичині, Трансильваніїй на Буковині в руслі зовнішньополітичних подій виглядала досить небезпечною. Вони загрожували комунікаціям російської армії у Молдові та Волощині. Спроби Дунайської армії після переправи через Дунай розвинути успіх на південному березі в цих умовах були пов'язані 3 великим ризиком. Удар австрійців по флангу i тилу армії генерала Горчакова міг спричинити повний розгром. Російська військова розвідка фіксувала переміщення i зосередження великих мас військ, заготівлю австрійцями значної кількості продовольства, розробку доріг в тилу армії і спорудження земляних укріплень навколо ключових міст Галичини і Буковини [18, л. 3-9, 34-39]. „Рух військ в областях Австрійської монархії триває безперервно, особливо з Богемії, залізницею полки перевозять до Галичини i Трансильваніï" [10, с. 2]. 
За таємним розпорядженням російського уряду почалися приготування до вивозу з губернського Кам'янця архівів установ, цінних в історичному плані предметів та фінансів. 15 червня 1854 p. губернатор кн. В'яземський видав таємне розпорядження щодо пакування документації та речей. 24 липня 1854 р. новий губернатор М. Степанов доповів про повну готовність губернських установ до негайної відправки. У районі Кам'янцяПодільського цілодобово (змінюючись через 3-6 днів) чергувало 900 селянських возів. Розглядалася можливість повної евакуації усіх установ до Вінниці чи Брацлава, а для їх нормальної роботи на новому місці частину архівів та документів почали перевозити з 27 липня [31, с. 78-79]. Водночас, крім приготувань до відведення углиб імперії важливих закладів та установ, у таких містах, як Кишинів, Балта, Херсон та Кам'янець-Подільський були посилені цілодобові військові караули та встановлені пункти контролю на виїздах $[13$, л. 1-2, 8].

$\mathrm{Bce}$, що можна було зробити, то це якнайкраще зміцнити прикордонне угрупування. Відповідно до планів фельдмаршала I. Паскевича, в разі наступу австрійців росіяни неминуче змушені б були відступати. Терміново, навпроти Буковини, між Кам'янцем-Подільським і Фокшанами, під начальством генерала Шабельського сформували загін зі всього, що було під рукою: 3 підрозділів 6-ї піхотної дивізії, розташованої між Баксу i Батушанами, резервної бригади 11-ї піхотної дивізії, 1-го драгунського полку, який стояв у Фокшанах, Текучо і Баксу, i тактичного резерву - двох кірасирських дивізій, що розмістилися на тісних квартирах в околицях Нової Ушиці у Подільській губернії [28, л. 1-2 об.]. Ці дивізії отримали можливість маневрувати по обох берегах Дністра, і за потреби могли через Могилів-Подільський або Бєльці йти назустріч австрійським військам, якщо б ті вступили до Молдови; або в район Кам'янцяПодільського, в разі появи цісарських військ у Подільської губернії мали відступати на Брацлав. I зовсім ілюзорні надії були на міфічне підкріплення двох батальйонів Резервної бригади, що „[...] мали залишитися в Хотині, до тих пір поки не підійдуть 22 батальйони піхоти і 78 ескадронів кавалерії з двома донськими козачими полками і одним уральським" [15, л. 9-11].

Далекоглядність I. Паскевича йому не зрадила. Під дипломатичним тиском Австрії, яка вимагала виведення російських 
військ 3 турецьких володінь не пізніше 30 квітня 1854 p. i виставила в Трансильванії 30 тисячний корпус, росіяни змушені були відступати. 315 липня до кінця серпня угрупування російських військ покинуло князівства і відступило в межі імперії. 10 серпня на їх територію вступили австрійці, а турецькі війська повернулися на правий берег Дунаю. 3 метою зміцнення оборони кордонів російське командування змушене було передислоковувати значні військові сили 3 внутрішніх губерній і намагатися зосередити на важливих напрямках необхідну кількість військ [26, арк. 2-8].

Спочатку був отриманий наказ царя про відправку військ на зимові квартири до Київського генерал-губернаторства: 6, 8, 9, 10 та 11-ту піхотні дивізії з артилерією, 3 і 4-й стрілецькі батальйони, 3 i 4-й саперні батальйони та частину кавалерії. В Бессарабії залишилися війська 5-го піхотного корпусу і 12 піхотна дивізія [12, л. 44-47]. Це пояснюється міркуванням командування щодо необхідності: 1) дати можливість протягом зими поповнити особовий склад замість втрат від хвороб та бойових дій; 2) отримати зимові однострої та все необхідне для продовження війни [37, с. 144 - 145]. Одночасно ретельно готувалися позиції для російської армії за річкою Дністер, відступ до якої був дуже вірогідним. Після висадки англо-франко-турецьких військ в Євпаторії та їх перемог, Микола I висловив побоювання, що союзники можуть прорвати оборону та захопити українські землі російської корони. Тому 13 серпня 1854 р. імператор дав згоду на формування спеціальних загонів для ведення партизанської війни у Київській, Подільській та Волинській губерніях [21]. Такий наказ було віддано лише після переконливої та обгрунтованої доповідної записки генерала Горчакова про реальну можливість появи австрійців у губерніях Правобережної та Південної України та необхідність розгортання руху спротиву серед місцевих мешканців. Врешті-решт страх царя втратити чималу частку імперії переміг над реальністю дати зброю в руки власним підданим [14, л. 2-3, 19-38].

3 моменту початку активних бойових дій на Кримському півострові, які спричинили значні людські та матеріальні втрати у польових полках російської армії, виникла потреба в їх поповненні [6, с. 81]. 3 початку 1855 р. таким джерелом стала колишня Дунайська армія, перейменована на той час у Південну. Вона 
розташовувалася у Бессарабії і на Поділлі під командуванням генерала О. Лідерса, і саме 3 неї періодично забиралися нові частини на посилення оборони Севастополя [19, арк. 4-9]. Таким чином, на весну цього ж року в ній залишилося лише 50000 солдат i офіцерів, що було явно недостатньо для оборони Бессарабії i Київського генерал-губернаторства [17, арк. 1-14, 15-17]. Небезпека окупації австрійцями, яка загрожувала цим територіям 3 самого початку війни, продовжувала існувати і тільки обмежений економічно-фінансовий потенціал Австрії утримував іiі від агресивних дій проти Росії [27, л. 71-74, 98-105].

Водночас вищому військовому і цивільному командуванню стало зрозумілою безперспективність зусиль 3 оборони Севастополя [21]. Фельдмаршал I. Паскевич вважав, що стратегічне значення міста вичерпувалося Чорноморським флотом, який там базувався. „Якщо б в Криму не було Севастополя, то ніхто й не подумав би нападати на Крим, а нам не довелося б його захищати. Порівняйте невдалі дії у Криму 3 тими наслідками, які можуть нас очікувати в разі війни з Австрією на західному кордоні, - писав він генералу Горчакову. 3 одного боку, втрата 16 кораблів, з іншого, втрата спочатку 4-х губерній 3 9 мільйонами мешканців (він мав на увазі Бессарабську область та губернії Київського генерал-губернаторства - А. С.), а потім, цілком можливо, й втрата Польщі, тобто 15 мільйонів населення та кращих наших провінцій, які противник може захопити без бою, і звідкіля ми його потім не скоро виженемо"'[8, л. 21-24].

Після падіння Севастополя Олександр II зрозумів, що потрібно захистити губернії, які перебували в небезпеці з боку західного сусіда, через відновлення боєздатності Південної армії [24, л. 106-112]. Скорочення військ в Криму і повернення більшої частини полків на Поділля мало відновити їх довоєнну кількість. Непотрібна Кримська армія почала передавати резерви для посилення Південної. 3 чотирнадцяти дивізій, які перебували на півострові, було вирішено залишити там тільки сім. Відповідно, склад Південної армії збільшився до семи дивізій з 112 батальйонів, а незабаром нараховував 128 батальйонів, 44 дружини державного ополчення, 209 ескадронів, 45 козачих сотень, 368 польових і 128 кінних гармат [25, л. 9, 149-152].

До кінця 1855 р. російські війська на Поділлі були готові до протидії Австрії набагато краще, чим навесні-влітку. Полки армії постійно посилювалися особовим складом та спорядженням, 
чиновництво губернії й населення поступово позбувалися панічних настроїв [16, л. 4-7]. Протягом року за наказом подільського губернатора було сформоване Кам'янецьке державне ополчення, яке здійснювало охорону важливих об'єктів та було потенційним джерелом поповнення військ [35, арк. 6-17]. Дворянство опікувалося питаннями забезпечення одностроями, продовольством, створенням польових аптек та розміщенням особового складу [38, арк. 1-3, 9-16]. Поступово суспільне життя в губернії входило у мирну колію. Після радісної новини про розпуск австрійським командуванням своїх військ у Галичині і Буковині по домівках, побоювання розвіялися остаточно [33, л. 133 об.-134]. Отримавши у грудні 1855 р. австрійський ультиматум, Олександр II погодився виконати усі його пункти, таким чином визнавши поразку Російської імперії, що дало привід для початку мирних перемовин.

Висновки й перспективи подальших досліджень. Агресивна зовнішня політика Російської імперії періоду правління царя Миколи I підкріплювалася існуванням величезної регулярної армії, яка й була іiї основним та дієвим інструментом. Бажання розширення меж імперії через знищення Туреччини та встановлення гегемонії на Балканах вкотре наштовхнулося на колективний спротив європейських держав. В ході цього протистояння реально існувала вірогідність повної військової поразки на південно-західних рубежах імперії Романових, i тільки нерішучість Австрії врятувала іiі від втрати Царства Польського, Правобережної України та Бессарабії. Прорахунки у стратегічному плануванні оборони, непрофесійність генералітету та технічна відсталість були головними причинами поразок росіян, за які розплачувалися життями прості солдати.

1. 1853. Июня 14. О движении Российских войск в Придунайские Княжества // ПСЗРИ-ІІ. Т. XXVIII. Отд. 1. С. - Петербург: Тип. II Отд. Собств. Е.И.В. канц. 1854. № 27344. С. 289-290.

2. 1854. Февраля 21. О Объявлении на военном положении Царства Польского и губерний: Курляндской, Ковенской, Виленской, Гродненской, Волынской и Подольской // ПСЗРИ-II. Т. XXIX. Отд.1.С.-Петербург: Тип. II Отд. Собств. Е.И.В. канц. 1855. № 27946. С. 192-193.

3. Алабин П. В. Четыре войны. Походные записки в 1849, 1853, 1854-56, 1877-78 годах. Ч. 2. 2-е изд., доп. Москва: Типо-лито-я т-ва И. Н. Кушнерев и К., 1890. 332 с. 
4. Аратовский В. Л. Обзор распоряжений по продовольствию Действующей армии в1831, 1848, 1849, и в 1853-1855 годах//изд- е ред. журнала Военный Сборник. Санкт-Петербург: тип. департамента уделов, 1874. С. 7; 12.

5. Бескровныій Л. Г. Русская армия и флот в XIX в. Военно-экономический потенциал России. - Москва: Наука, 1973. $-610 \mathrm{c}$.

6. Гальчак С. Д. Ратна слава Вінничини : Час. Події. Особистості. Вінниця, 2015. С. 81.

7. Докладная записка фельдмаршала Паскевича в Военное министерство 1853 г.// Российский государственный военно-исторический архив (РГВИА). Ф. 14013. Оп. 1. Д. 1.70 л.

8. Записка генерал-фельдмаршала Паскевича Горчакову о предстоящих военных действиях 1855 г.//РГВИА. Ф. 481. Оп. 1. Д. 13.40 л.

9. Иностранные известия // Русский инвалид. 27 февраля 1854 г. № 48. С. 3.

10. Иностранные известия // Русский Инвалид. 4 июня 1854 г. № 124. С. 2.

11. Криволапов А. А. Фельдмаршал И. Ф. Паскевич и проблема стратегии России в Восточной войне 18531856 гг. // Русский сборник. Военная политика императора Николая I / ред-сост. О. Р. Айрапетов и др. Москва: 2009. Том VII. C. 247; 252; 257.

12. Назначение войск для наблюдения за р. Прутом по обратном переходе армии через оную. Диспозиции на случай наступления турок или австрийцев. Сведения о неприятеле 1854 г. // РГВИА. Ф. 846. Оп. 9. Д. 3374. 209 л.

13. Наличное состояние войск и расчет караульных постов по Кишиневу, Балте, Херсону и Каменцу-Подольскому. Передвижение войск Южной армии с дислокациями и маршрутами 1855 г. // РГВИА. Ф. 846. Оп 9. Д. 3365.17 л.

14. О народном сопротивлении в случае вторжения неприятеля в пределы России. Всеподданнейшая записка кн. Горчакова о народном вооружении и партизанской войне. Манифест о сопротивлении неприятелю, ложно поднятый крестьянами Киевской губернии, возмущение в разных уездах оной губернии 1855 г. // РГВИА. Ф. 846. Оп. 9. Д. 3312.524 л.

15. О передвижении частей русских войск к границе с Австрией 7.11.1854 г. // РГВИА. Ф. 38. Оп. 4. Д. 1057. 31 л.

16. Отзывы Военного министра и предписания главнокомандующего Южной армией. Размещение армии на случай войны с Австрией. Образование Средней армии. Число батальонов, эскадронов и орудий в Западной, Средней и Южной армиях 1855 г. // РГВИА. Ф. 846. Оп. 9. Д. 3403.8 л. 
17. Переписка з Подільським цивільним губернатором, військовими частинами про розквартирування і постачання військ 7.01.-3.12.1859 p. // Держархів Вінницької області. Ф. Д-200. Оп. 1. Спр. 221. 23 арк.

18. Переписка Командующего армией с Военным министром о плане и ходе военных действий, вообще, и о некоторых в частностях. Сведения о видах и предположениях неприятеля и Австрии, о ходе вооружения австрийской армии и о движении ея к границам Дунайских княжеств 1854 г. // РГВИА. Ф. 846. Оп. 9. Д. 3333.302 л.

19. Переписка Подільського губернського правління 3 Київським генерал-губернатором щодо прибуття військ до м. Кам'янця-Подільського, про витрати земських коштів, про допомогу повітовим містам на утримання військ 31.12.1855-12.06.1856 р. // ЦДІАК України. Ф. 442. Оп. 86. Спр. 244. 479 арк.

20. Петров А. Н. Война России с Турцией. Дунайская компания 1853 и 1854 гг. Том I. Санкт-Петербург: Военная типография, 1890. 205 c.

21. Пилявець Р. Севастополь - місто української слави. Про українців у Кримській війні// Українська правда. Історична правда. Електрон. Ресурс: www.istpravda.com.ua/articles/ 2014/07/9/143699 (дата звернення 12.01.2015).

22. Подчинение главнокомандующему Южной армией Киевской, Подольской и Херсонской губерний в военном отношении. Размещение госпиталей. Выписка из журнала войск, под начальством барона Остен-Сакена, с 10 ноября 1853 по 10 ноября 1854 г. Движение и расквартирование войск в Бессарабской области и других губерниях. 3.11.18549.04.1855 г. // РГВИА. Ф. 846. Оп. 9. Д. 3330.23 л.

23. Покровский М. Н. Внешняя политика России в первые десятилетия XIX в.// Дипломатия и войны царской России в XIX столетии. сб. ст. Москва: 1923. С. 6.

24. Приказ Александра II об усилении Южной армии 1855 г. // РГВИА. Ф. 14014. Оп. 2. Д. 68. 12 л.

25. Приказ Военного министерства об передаче некоторого количества войск Крымской армии в распоряжение штаба Южной армии 30.11.1856 г. //РГВИА. Ф. 38. Оп. 4. Д. 1419. 224 л.

26. Про розквартирування військ 2-го піхотного корпусу 11.12.1855 р. // Держархів Хмельницької області. Ф. 243. Оп. 1. Спр. 12. 15 арк.

27. Разные сведения об неприятеле и об австрийцах 1853-1856 г. // РГВИА. Ф. 846. Оп. 9. Д. 3323.309 л.

28. Распоряжения на случай перехода неприятельских войск через р. Пруг. Зимние квартиры войск в 1854-1855 гг. 
Образование в Киевской и Волынской губерниях особого отряда, под начальством генерала Гельфрейха. Проведение Московско-Киевской и Киевско-Николаевской телеграфных линий и донесения с театра войны телеграфическими депешами 1854-1855 г. // РГВИА. Ф. 846. Оп 9. Д. 3372.4 л.

29 Реєнт О. П. Чому Кримська війна 1853 - 1856 рр. стала явищем міжнародного суспільного життя? // Історія Криму в запитаннях та відповідях/відп. ред. В. Смолій; упорядн. Г. Боряк. НАН України. Інститут історії України. Київ: 2015. С. 273.

30. Сведения о передвижении некоторых частей войск, в конце 1852 года. Распоряжение о выступлении за р. Прут войск 3-го пехотного корпуса. Копии с докладом бывшего департамента Генерального штаба по части передвижения и расположения войск 3, 4 и 5-го пехотных корпусов на юге России и за границею 1853 г. // РГВИА. Ф. 846. Оп. 9. Д. 3310а. 11 л.

31. Скрипник А. Ю. Державні установи Подільської губернії 1793-1914 рр.; монографія / Кам'янець-Подільський, 2012. C. $78-79$.

32. Скрипник $A$. Ю. Російський військовий чинник у суспільно-політичному та економічному розвитку Правобережної України (1792-1865рр.): монографія/ Кам'янецьПодільський: Видавець ФОП Зволейко Д. Г., 2016. 612 с.

33. Сообщение о роспуске австрийских войск на Буковине и в Галиции 17.10.1855 г. // РГВИА. Ф. 14014. Оп. 2. Д. 243. 13 л.

34 Сосредоточение войск в северной Бессарабии, также близ Одессы, Николаева и у прибрежных пунктов Азовского моря. Состав и число войск, движение их, диспозиции, приказания, известия о неприятеле 1854 г. // РГВИА. Ф. 846. Оп. 9. Д. 3335. 210 л.

35. Справа про комплектування Кам'янецького ополчення 24.04.-3.05.1855 p.//Держархів Хмельницької області. Ф. 122. Оп. 2. Спр. 33. 19 арк.

36. Ульянов И. Э. Регулярная пехота 1801-1855. История Российских войск. Москва : АСТ, 1996. 241 с.

37. Ушаков Н. И. Записки очевидца о войне против Турции и западных держав (1853-1855). Предисловие // XIX век. Кн. вторая. Москва: 1872. 489 с.

38. Циркуляри військового Губернатора м. Кам'янцяПодільського і Подільського цивільного губернатора про державне ополчення, спорядження ополченців, збори ратників до державного ополчення i про продовольче забезпечення, облаштування польових аптек тощо 17.03. 4.06.1855 р. // Держархів Хмельницької області. Ф. 123. Оп. 1. Спр. 112, арк. 51 
Надійшла до редколегії 27.06.2017 р.

Рецензент: В.С. Виздрик, доктор історичних наук, доцент, професор кафедри гуманітарних наук Національної академії сухопугних військ імені гетьмана Петра Сагайдачного, м. Львів.

Skrypnyk A. Y.

ON THE EVE OF A CATASTROPHE.

ORGANIZATION OF DEFENSE OF PODILLIA DURING THE EASTERN (CRIMEAN) WAR OF 1853 - 1856.

The article examines preventive defense measures of the Russian military command concerning a probable attack of Austrian Empire troops on the territory of Podillia and Bessarabia provinces in 1854-1856. It proves that the Russian autocracy did not have prepared tactical plans of border protection by the troops, and diplomatic discalculations and disregard of foreign policy in Eastern Europe and the Balkans almost brought Russia to the brink of destruction of its armed forces on the territory of Right-Bank Ukraine.

Key words: Russian Empire, Podillia, Bessarabia, Eastern War, army, defense. 